Georgetown University Law Center

Scholarship @ GEORGETOWN LAW

2019

\title{
Janet Halley and the Art of Status Quo Maintenance
}

Lama Abu-Odeh

Georgetown University Law Center, la34@law.georgetown.edu

This paper can be downloaded free of charge from:

https://scholarship.law.georgetown.edu/facpub/2034

https://ssrn.com/abstract=3124327

2 Soc. Just. \& Equity L.J. 5

This open-access article is brought to you by the Georgetown Law Library. Posted with permission of the author. Follow this and additional works at: https://scholarship.law.georgetown.edu/facpub

Part of the Law and Gender Commons, and the Sexuality and the Law Commons 


\title{
Janet Halley and the Art of Status Quo Maintenance
}

\author{
Lama Abu Odeh ${ }^{1}$
}

Over the past few years, Janet Halley emerged as one of the most avid critics of campus rape feminist activists, activists who push for the reformulation of university investigative rules to shift the burden of proof from the accuser to the accused. Halley contends that Title IX policies, embedded with affirmative consent, are not only procedurally unsound, but bad for boys, bad for sex, and bad for feminism, charging its agenda with "radical feminism" influences. Halley's stance on campus rape is consistent with her long-held "queer theory" and its anti-feminist deregulatory drive. In this article, I argue that Halley's "queer theory," which she developed by polemically critiquing Catharine Mackinnon's work, in an attempt to extol "sex positivism" in legal academia with the dignity of "fancy" theory, in effect stands Mackinnon on her head. By inverting Mackinnon's gender/sex constructions, Halley's theory fronts as an idealist proposition indicting feminism with the invention of sexual injury and inspiring women to manipulate innocuous facts into scandalous protest.

Flipping Mackinnon's equality approach when it comes to legal rules takes Halley to the right of "consent" where Mackinnon had gone to its "left." By mirroring Mackinnon's critique of "consent," except from the right, Halley's theorizing echoes a sexual libertarian agenda without/before feminism. It defends male sexual entitlement avant liberal feminism.

Ideologically, such theoretic formulations, along with the bundle of rules they advocate for, are designed to keep pressure on ruling liberal feminism from departing in its understanding of sex from the "pathology" model whereby all men are good except for those who are "pathologically" violent (classical liberalism) in the direction of understanding sexual entitlement as part of the social construction of maleness. By clamoring from the right of liberal feminism, mainstream liberal feminism is kept in check.

In order to explain the various elements of Halley's theories on gender/sex and expose their underlying pre-feminist "classical liberal" orientation, I position her comparatively within the gender/sex theories of the non-liberal academic left: Mackinnon (her antagonist), Duncan Kennedy (her ally), and Judith Butler (her theoretical homebody). I analyze the way these theorists used the theoretical traditions of Marxism, post-modernism, and post-structuralism to posit a relationship between gender and sex: sex is gender simpliciter (Mackinnon), gender is sex simpliciter (Halley), and the split difference between gender and sex (Kennedy). This exercise illuminates the doctrinal approaches of each theory, be it to the left or right of consent. I conclude the article with a succinct critique of

\footnotetext{
${ }^{1}$ Lama Abu Odeh, Professor of Law, Georgetown Law Center. I would like to thank my research assistants Jared Allen and Melani Mennella for their indispensable help. Their dedicated research, incisive comments, and careful reformulation made this text possible. I owe them a great deal. I would like to specially thank Melani for offering a beautiful and thoughtful re-articulation of my words. Her contribution was invaluable.
} 
Halley's theoretic excursions and argue Halley is guilty of five themes of "misrecognition:" (A) theoretical, oscillating between an antagonism to the very idea of sexual injury and proposing a neutral proceduralist approach to identifying it; (B) political, targeting radical feminism with her critique while smashing liberal feminism on the way; (C) sociological, reading women's sexual injury through the eyes of an "uninjurable" promiscuous gay man advocating a radical sexual ideology; (D) ideological, attempting to ally her sexual libertarianism with the left when the ideological universe it travels is "classical liberalism," definitively, the left's most pronounced critic; and (E)historical, advocating a "sex positive" agenda in radically sex positivist times.

\section{TABLE OF CONTENTS}

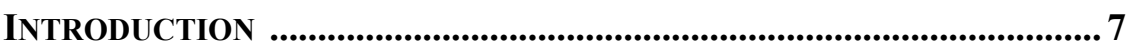

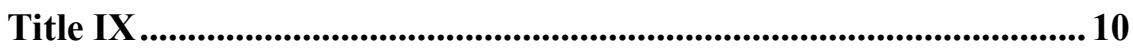

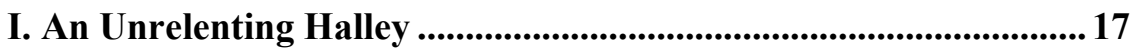

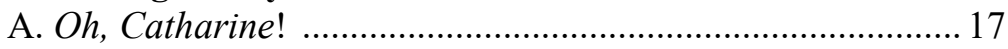

B. Aping Mackinnon............................................................... 19

C. Inducing Ambivalence in Others.......................................... 24

II. Theories on Gender/Sex by the Non-Liberal Academic Left....... 27

A. Catharine Mackinnon on Gender/Sex (Marxist-like) .........28

B. Judith Butler on Gender/Sex (Foucault-like) .......................31

C. Duncan Kennedy's Theory on Gender/Sex: "Sexy Dressing:" Splitting the Difference between Liberal Feminism and Radical Feminism ....................................... 35

D. Janet Halley's Queer Theory on Gender/Sex: Radical PostModernism

III. The Misrecognitions of Halley's “Queer” Sex Libertarian

Project...................................................................................................................... 43

A. The Problem of Theoretic Misrecognition .......................... 43

B. The Problem of Political Misrecognition ............................. 44

C. The Problem of Sociological Misrecognition....................... 44

D. The Problem of Ideological Misrecognition ....................... 44

E. The Problem of Historical Misrecognition............................ 44

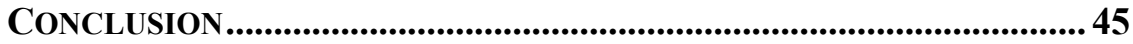




\section{INTRODUCTION}

As I write this introduction, social media's \#MeToo campaign has swept the globe, inviting women to unapologetically own and narrate their sexual assault experiences. ${ }^{2}$ In a script-like sequence, men, célébre or not, deny, apologize, and resign, risking lawsuits and prosecution. Women of all ages, races, ethnicities, and nationalities have stepped forward to voice intimate stories that are all too relatable, and all too common. Each story shares a similar narrative structure: admittance of reluctance ("I sat on this story for a while"), underlying emotion ("I suffered in isolation"), sense of empowerment ("a call to action by other women transformed my depression into outward rage"), and a courageous act of defiance ("enough is enough"). To anyone watching, the truth of "femaleness," and feminism at large, is proving global. This global stride of empowerment and its viral momentum is a reckoning for feminists of my generation.

It seems like only yesterday, the various factions of the academic left, especially the women of the left who troubled themselves to write about feminism, denounced its universalist claims. ${ }^{3}$ The anti-imperialists

\footnotetext{
${ }^{2}$ Somini Sengupta, The \#MeToo Moment: What Happened After Women Broke The Silence Everywhere, New York Times (Dec. 22, 2017), https://www.nytimes.com/2017/12/22/us/the-metoo-moment-what-happenedafter-women-broke-the-silence-elsewhere.html; Stephanie Zachareck et. al., The Silence Breakers, Time (Dec. 18, 2017), http://time.com/time-person-of-theyear-2017-silence-breakers/.

${ }^{3}$ For a definition of "women of the left" see, Shulamith Firestone, THE Dialectic OF SEX: THE CASE For FeMINIST Revolution 37-45 (1970) (outlining several subsets of "politicos" which exist between conservative feminism and radical feminism: " $[t]$ he politicos of the contemporary women's movement are those women whose primarily loyalty is to the Left. ("The Movement") rather than to the Liberation Movement's Proper. Like the politicos of the Progressive Era, contemporary politicos see feminism as only tangential to "real" radical policies, instead of central, directly radical in itself ...."), a definition that by large holds true till today.
} 
decried its universalist claims as "imperialist," the multiculturalists decried its universalist claims as "Eurocentric," the anti-racists decried its universalist claims as "white", ${ }^{6}$ and the post-modernists, attached to their localism creed, decried its universalist claims as, expectedly, "universalist."7

Notwithstanding the status of feminism, the various factions of the left are currently suffering a crisis of confidence. Their erudite claims, which brimmed academic journals for decades, have caved under the pressures of recent history. Retreat of the Unites States into isolationism and the global threat of terrorism has left anti-imperialists with a misplaced paranoia. As foreign empires, willingly or unwillingly, withdraw to the benefit of regional powers, the long imagined "victims" of anti-imperialist literature often revert to unspeakable acts of destruction. The pro-Islam multiculturalists find themselves struggling to dissociate from the culturalist claims of ISIS, the state that implemented Islamic Law in its most 'perfect' form, the multi-culturalists' dream of anti-Western otherness. The anti-racists struggle with the impact of vast economic disparity, indiscriminately submerging all races in its wake, begetting a Sanders and a Trump in renunciation of the pro-race Clinton. And still, the

\footnotetext{
${ }^{4}$ Deepa Kumar, Imperialist Feminism, 102 Int’L Socialist Rev. (2015), https://isreview.org/issue/102/imperialist-feminism.

${ }^{5}$ SABA MAHMOOD, Politics OF PIETY: The Islamic ReVIVAL AND the FEMINIST SUBJECT, 1-2 (2005).

${ }^{6}$ See generally Kimberle Crenshaw, Demarginalizing the Intersection of Race and Sex: A Black Feminist Critique of Antidiscrimination Doctrine, Feminist Theory and Antiracist Politics, 1989 U. CHI. Legal F. 139; Angela Harris, Race and Essentialism in Feminist Legal Theory, 42 STAN L. REV. 581 (1990).

${ }^{7}$ See generally Karen Engle, Liberal Internationalism, Feminism, and the Suppression of the Critique: Contemporary Approaches to the Global Order in the United States, 46 HARV. INT'L L. J. 427 (2005).
} 
post-modernists struggle to distinguish their brand of critical irrationalism and "it's all political folks" from Trump's irrationalism and hyper politicization of the liberal structure of the state.

I previously wrote critiquing the anti-imperialists ${ }^{8}$ and the multiculturalists. ${ }^{9}$ This paper confronts the post-modernist left, ${ }^{10}$ as represented by the writings on feminism ${ }^{11}$ by Janet Halley and Duncan Kennedy of Harvard Law School. Both Halley and Kennedy wrote critiquing feminism from a "sex positivist" perspective, and both exploit the postmodernist theories popular amongst their generation of leftist academics. Their political positions on feminism differ; Kennedy offers himself as a pro-sex ally of feminism and Halley swears to its destruction lock, stock,

${ }^{8}$ Lama Abu-Odeh, That Thing You Do: Comment on Joseph Massad's “Empire of Sexuality, " AL-AKHBAR ENGLISH (Mar. 25, 2013) available at http://english.al-akhbar.com/node/15350; Lama Abu-Odeh, Holier Than Thou?: The Anti-Imperialist Versus the Local Activist, OPEN DEMOCRACY: 50.50 GENDER, SEXUALITY AND SOCIAL JUSTICE (May 04, 2015), available at https://www.opendemocracy.net/5050/lama-abu-odeh/holier-than-thouantiimperialist-versus-local-activist.

${ }^{9}$ Lama Abu Odeh, Secularism's Fault, 2 Feminist Dissent 148 (2017); Lama Abu Odeh, Book Review of The Impossible State By Wael Hallaq, 46 INT'L. J. MIDDLE E. STUD. 216 (2014).

${ }^{10} \mathrm{I}$ am referring to the post-modernist left that built a base at HLS graduate program under the auspices of Duncan Kennedy and his ex-student, David Kennedy. The brilliance of the former and the fundraising and organizational skills of the latter combined to create an academic scene, mostly among foreign graduate students, that worked at "academizing" the post-modernist strand of long dead CLS, while obscuring the other strands. When Janet Halley joined the faculty of HLS in 2000, she became synonymous with the scene. Her brand of anti-feminism, which she dubbed "Queer Theory" slowly became the official line of the scene, displacing the loose alliance with radical feminism, represented in Duncan Kennedy's "Sexy Dressing" article (discussed below). Kennedy offered this article to his supervisees in the nineties, including me. Halley pushed Kennedy's difference splitting strategy into a crisis and he conceded to her "leadership" of the "girls"- referred to by the Kennedys as "Janet's girls" by sending "feminist" students her way to share in supervision. Halley worked quite efficiently by redirecting feminist students' animus away from men and at feminism itself. Soon enough the feminist became "queer".

${ }^{11}$ Abu-Odeh, supra note 9. 
and barrel. ${ }^{12}$ Nevertheless, they navigate the same critical legal left theoretic universe, they share mentees, and they consider themselves ideological allies, especially on the issue of Title IX. As I elucidate below, Kennedy's position proves so "fragile" in its articulation of its profeminist ally-ship that it easily collapses into that of Halley's.

\section{Title IX $\mathbf{X}^{13}$}

The recent battle Halley waged over HLS's Title IX policies, seems an apropos occasion to take on her writings. Halley's freshly branded, Fairness for All Students ${ }^{14}$ movement has catapulted her into the public square, leading to interviews by the New York Times ${ }^{15}$ and mainstream liberal media outlet, NPR. ${ }^{16}$ Halley’s colleague and protégé, Professor Jeanne Suk, challenged the "always believe [the victim] credo" in the New Yorker, ${ }^{17}$ and journalist, Emily Yoffee, followed suit in the

12 John Sutherland, The Ideas Interview: Janet Halley, THE GuARDIAN (Aug. 06, 2006), https://www.theguardian.com/world/2006/aug/08/gender.academicexperts. ${ }^{13}$ Title IX, 20 U.S.C. $§ 1681-1688$, added 1972 by amendment to the Higher Education Act of 1965 (HEA), "No person in the United States shall, on the basis of sex, be excluded from participation in, be denied the benefits of, or be subjected to discrimination under any education program or activity receiving federal finance assistance."

${ }^{14}$ See Elizabeth Bartholet, Nancy Gertner, Janet Halley, \& Jeannie Suk Gersen, Fairness For All Students Under Title IX (Aug. 21, 2017)

http://nrs.harvard.edu/urn-3:HUL.InstRepos:33789434.

${ }^{15}$ Emily Bazelon, The Return of the Sex Wars, N.Y. TIMES MAGazINE (Sept. 10, 2015), https://www.nytimes.com/2015/09/13/magazine/the-return-of-the-sexwars.html? $\mathrm{r}=0$.

${ }^{16}$ All Things Considered, Betsy DeVos Launches Reform Effort on Campus Sexual Assault Policy, NPR (Sept. 26, 2017), https://www.npr.org/2017/09/26/553799166/betsy-devos-launches-reformeffort-on-campus-sexual-assault-policy.

${ }^{17}$ Jeannie Suk Gersen, Shutting Down Conversations About Rape at Harvard Law, NEw YORKER (Dec. 11, 2015), https://www.newyorker.com/news/newsdesk/argument-sexual-assault-race-harvard-law-school; Jeannie Suk Gersen, Besty DeVos, Title IX, and the "Both Sides" Approach to Sexual Assault, NeW YORKER (Sept. 08, 2017), https://www.newyorker.com/news/news-desk/betsydevos-title-ix-and-the-both-sides-approach-to-sexual-assault; Jacob Gersen \& Jeannie Suk, The Sex Bureaucracy, 104 CAL. L. R. 881 (2016). 
Atlantic. ${ }^{18}$ Joined by libertarians and conservatives, Halley proves to be one of the most avid, outspoken opponents of the Obama Administration's Title IX revival. ${ }^{19}$ Halley was nonplussed, if not outraged, with HLS's feminist student activists who protested the administration to properly investigate and adjudicate sexual assault charges on campus. Reactively, Halley circulated two petitions to mobilize HLS faculty in a contentious policy debate surrounding sexual harassment and violence. ${ }^{20}$ In addition to Kennedy, nearly thirty faculty members cosigned the petition, mostly aging men. Halley appeared incredulous that feminist student activists had not acknowledged sex positivism as the victor and that sexual joie de vivre was deemed the norm of the day. ${ }^{21}$ If you were fucked in drunken stupor

${ }^{18}$ Emily Yoffe, The Uncomfortable Truth About Campus Rape Policy, ATLANTIC (Sept. 06, 2017), https://www.theatlantic.com/education/archive/2017/09/the-uncomfortabletruth-about-campus-rape-policy/538974/.; Emily Yoffee, The Question of Race in Campus Sexual-Assault Cases, ATLANTIC (Sept. 11, 2017), https://www.theatlantic.com/education/archive/2017/09/the-question-of-race-incampus-sexual-assault-cases $/ 539361 /$.

${ }^{19}$ Joe Biden, U.S. Vice President, Address at University of New Hampshire on behalf of SHARPP Campaign (Apr. 04, 2011). "We are the first administration to make it clear that sexual assault is not just a crime, it can be a violation of a woman's civil rights." Joe Biden's landmark announcement was followed by the Office of Civil Rights' "Dear Colleague" letter. The 19-page statement outlined the legal foundation of Title IX, which dates back to Alexander v. Yale, 631 F.2d 178 (2d Cir. 1980) (finding that "academic advancement conditioned upon submission to sexual demands constitutes sex discrimination in education"). The case marked the first sexual harassment case brought under Title IX. https://www.youtube.com/watch?v=hKjgHV7GpsM

${ }^{20}$ Matthew Q. Clarida, Law School Profs Condemn New Sexual Harassment Policy, THE HARVARD CRIMSON (Oct. 15, 2015), http://www.thecrimson.com/article/2014/10/15/law-profs-criticize-new-policy/.

${ }^{21}$ The sex wars, born in the late seventies, stratified two antithetical ideological differences of feminism, pitting sexual repression against gender oppression. The pornography wars, quite literally, legal wars against pornography, became the posterchild for this dual. Mackinnon exposed the relationship between pornography and violence against women, proffering, “[p]ornography [as] a systemic practice of exploitation and subordination based on sex that differently harms women. The harm of pornography includes the dehumanization, sexual exploitation, forced sex, forced prostitution, physical injury, and social and sexual terrorism and inferiority presented as entertainment." To many, (including Halley) these notions flew in the face of sexual freedom, expression 
after a long night of fraternity partying, well, you just called it a "bad night." Halley charged the student activists with resuscitating radical feminism, a movement she has committed her legal academic career to denouncing by vehemently opposing the figure of Catharine Mackinnon. ${ }^{22}$

Confronting young student activists on the subject of rape, assault, and violence was a ballsy move for Halley. Campus rape activism found sympathetic ears in the Obama Administration, which backed compassionate policy with federal financing. ${ }^{23}$ Sensitive to a liberal president, the public and universities embraced stricter procedures and broader standards. Dismantling these institutional mores would require a cunning bullishness, a bullishness Halley never lacked. Her 2000 article, Sexuality Harassment, shook legal academia and subverted feminist constructs. ${ }^{24}$ Halley harnessed her testicular capital by calling for the deregulation of all sexual harassment in the workplace. She flatly declared regulation of sexual harassment bad for queers. ${ }^{25}$ In the feminist narrative, sexual harassment regulation was equated to the commemoration of girls' long struggle in the courts against boy employers' who demanded quid pro

and positivity. Though, Mackinnon gained traction in statutory reform against pornography, jurisdictional buy in was limited and temporary. See Andrea Dworkin, Catharine Mackinnon, Pornography and Civil Rights, A New Day for Women's Equality, 1988.

${ }^{22}$ Bazelon, supra note 15.

${ }^{23}$ Letter from Russlynn Ali, Assistant Sec'y for Civil Rights, U.S. Dep't of Educ., to Dear Colleague on Sexual Violence (Apr. 04, 2011), https://www2.ed.gov/about/offices/list/ocr/letters/colleague-201104.pdf. ${ }^{24}$ JANET Halley, Sexuality Harassment, in Left LegalisM/Left CRITIQUe 80 (Wendy Brown \& Janet Halley, eds. 2002) [hereinafter Sexuality Harassment]. ${ }^{25} \mathrm{Id}$. at $98-99$ ("Homosexual panic . . . can be extremely dysphoric. Some people might even say that having a homosexual panic experience at work was unwelcome and sufficiently severe to alter the conditions of their employment and create an abusive working environment. Under Oncale, they can sue for that."). 
quo, sexual favors, and poisoned the office with demeaning stereotypes and sexual innuendo. ${ }^{26}$ For Halley, these alleged feminist victories were procedural hurdles in the path of innocuous gay cruising in the office. ${ }^{27}$ Alas, nearly two decades later, Title IX, and affirmative consent, has become a perfect platform for Halley to extol her queer theory and bury feminism in its totality. ${ }^{28}$

${ }^{26}$ Mackinnon co-counseled Mechelle Vinson in the Supreme Court landmark decision recognizing sexual harassment as a violation of Title VII. See Meritor Savings Bank v. Vinson, 477 U.S. 57, 57-58 (1986) (finding a claim of "hostile environment" sexual harassment is a form of sex discrimination that is actionable under Title VII and the language of Title VII is not limited to "economic" or "tangible" discrimination. Equal Employment Opportunity Commission Guidelines fully support the view that sexual harassment leading to non-economic injury can violate Title VII). Sexual harassment also manifested in quid pro quo claims. See Gary v. Long, 59 F.3d 1391, 1395 (D.C.Cir.1995) (finding " $[\mathrm{t}]$ he gravamen of a quid pro quo claim is that a tangible job benefit or privilege is conditioned on an employee's submission to sexual black-mail and that adverse consequences follow from the employee's refusal"); Chamberlin $v$. 101 Reality Inc. $915 \mathrm{~F} .2 \mathrm{~d}$ at 783 (identifying a "quid pro quo harassment exists where a victim's response to unwelcome sexual advances affects "tangible aspects of her compensation, terms, conditions, or privileges of employment").

${ }^{27}$ Halley, supra note 24, at 98 ("'[T] he regulatory project would only make the problematic of wantedness more covert.... After all, it's not just the perverts who engage in scenes like those I've just affirmed as good who seek incoherent experiences in sex: I think most of us experience sex (when it's not routinized) as an alarming mix of desire and fear, delight and disgust, power and surrender, surrender and power, attachment and alienation, ecstasy in the root sense of the word and enmired embodiedness. Essential elements [of this] are enacted, I imagine, in many more sexual relationships than you would guess just by looking around the boardroom or seminar room, and the edgy experience of unwantedness in sex is probably cherished by more people than are willing to say so.").

${ }^{28}$ Affirmative consent policies, often referred to as Yes Means Yes Laws, differ by state and university. As defined by the National Sexual Violence Resource Center, "consent is voluntary, mutual and can be drawn at any time. Past consent does not mean current or future consent. There is no consent when there is force, intimidation or coercion. There is no consent if a person is mentally or physically incapacitated or impaired because one cannot understand the fact, nature, or extent of the sexual situation." Sex Without Consent Isn't Sex. It's Rape, It's on Us, (last visited Nov. 10, 2018) https://www.itsonus.org/wpcontent/uploads/2017/04/IOU-Consent-Discussion-Guide.pdf. Ironically, Halley argues this legal level of consent is a conservative state cooperative. See Janet Halley, The Move to Affirmative Consent, 42(1) SIGNS: J. OF WOMEN IN CULTURE \& SOC'Y 257, 258 (2016) ("the campaign for affirmative consent requirements is distinctively rightist and that it would be even more conservative 
Halley sharpened her theoretic teeth by repeatedly attacking the work of Catharine Mackinnon. ${ }^{29}$ It was through these attacks that she articulated and propagated her queer line. She misidentified ${ }^{30}$ the student activist agenda as "Mackinnonite." ${ }^{31}$ Invoking Mackinnon was invoking a long-term obsession and her project was to offer an alternative theoretic arsenal to displace Mackinnon within the ranks of the radical legal left. In short, Halley aspires to unseat radical feminism, as articulated by Mackinnon, and replace it with "Queer Theory" as the primary source of theory on how to understand gender and sex in the legal context. Her doctrinal project focused on the "de-regulation" of feminist injury-based rules in the name of sexual pleasure. Halley created a formal oppositional

than it is today if it were not making political compromises to its left with male paternalist elites.").

${ }^{29}$ Halley, supra note 24 at 91-92 ("The MacKinnon brief thus maintains the ontological supremacy of the male/female model by simultaneously evacuating sexual orientation of any distinct components and flooding it with gender understood as male superordination and female subordination. This is, I think, a big mistake ... This formulation causes the brief to argue that the homosexual orientation of the "perpetrator" [may be relevant.] Gay rights organizations have fought to close this route off ever since circuit courts first opened it, however, because it is also a quick and easy route to homophobia ...."); see also Bazelon, supra note 15.

${ }^{30}$ There is no evidence that campus rape activists were Mackinnonite. While they tried to push the "consent standard" to the "affirmative" type, their approach is too consent based to be Mackinnonite. Moreover, those activists saw Mackinnon's position on sex as "too prudish". They were "sex positivist," gender bending feminist activists whose agenda and discourse is unique to their generation that synthesizes the old battles within feminism (sex positivist vs. feminist) rather than allies itself with either strand. See generally VANESSA GRIGORIADUS, BLURRED LiNES: RETHINKING SEX, POWER, \& CONSENT ON CAMPUS (2017).

${ }^{31}$ Bazelon, supra note 15 ("Like Mackinnon, student activists see the law as a tool of resistance against oppression, usually though not exclusively perpetrated by men...To Halley, it's strange to hear feminists appealing to men to change their behavior while leaving women out of the equation. "I'm really troubled by this trend in which women are helpless and passive and men are the big responsible protectors," she said. "That's the ideology of the gilded cage. It's astonishing to see feminists reawakening it uncritically. If young people are going to have a robust role in creating the conditions they want to live in, feminists have to call off this ban...”). 
relationship between the equality branch of feminism and the sex positivist one. She raised the stakes for the libertarians/pleasurists, in the presence of the egalitarians/legal sex regulators. ${ }^{32}$ Halley, unsuccessfully, peddled her project in legal academia through footnotes in law review articles. Her devotees remain a small circle of foreign graduate students at HLS circulating within the scene of the post-modern CLS. ${ }^{33}$ Until Title IX surfaced that is, when Halley became somewhat of a public figure.

This article is divided into three sections. Section I exposes Halley's history of obsessive attacks on Mackinnon. I argue that Halley's critique of Mackinnon, in effect, stands Mackinnon on her head. Inverting Mackinnon situates Halley to the right of consent. Section II offers a comparative exercise of the gender/sex theories of Catharine Mackinnon, Judith Butler, Duncan Kennedy, and Janet Halley. I argue that Kennedy splits Mackinnon's theoretical line with liberal feminism on law, while aligning himself with post-modernist theories on culture and resistance. Halley pushes Kennedy's difference-splitting with radical feminism into a

\footnotetext{
${ }^{32}$ Halley's position is formalist because it mimics the conservative argument for laissez faire in the economy.. The conservative argument is that market regulation aimed at equality curbs the freedom of the employer and prohibits entrepreneurship The leftist response to this conservative argument has always been a corrective: the comparison is not between the freedom of some (entrepreneurs) and the equality of others (workers), but between the freedom of both or alternatively the equality of both. Halley's position is likewise conservative and legally formalist. She proffers that equality-based regulation curbs sexual freedom. And of course, the feminist answer to her position is the rhetorical question:, "Whose sex should prevail, mine or his? Whose gender should prevail, mine or his?" By attacking feminist regulation Halley argues for his sex, whether by design or by default. While Halley in Sexuality Harassment does not critique feminist regulation as it affects straight men in their social conflict with straight women, instead she posits that feminist regulation threatens gay sex, her position on campus rape devolves into a defense of sexual liberty in general which opens it up to the critique above.

${ }^{33}$ The once heady scene was a direct result of the David and Duncan Kennedy's strategic recruitment of graduate students. (This is an autobiographical statement by the author who was part of the scene.)
} 
crisis as she manipulates Butler's gender indeterminacy into radical gender voluntarism. This exercise includes a comparative analysis of the ideological positions of each theorist - radical Mackinnon, left liberal Kennedy, and radical libertarian Halley. I analyze the baseline theoretical traditions of these ideological positions by examining Marxism, postmodernism, and post-structuralism, as well as their espoused relationships between gender and sex: sex is gender simpliciter, gender is sex simpliciter, and the split difference between gender and sex. Lastly, I compare their respective doctrinal approaches - left of consent and right of consent. Through this deconstructed comparison, I assert that solely Mackinnon's social theory, with its pronounced social conflict approach, offers a nuanced and transformative rationale worthy of leftist embrace. The post-modernist/structuralist approaches of Butler, Kennedy, and Halley, in their rejection of social theory, reproduce classical liberalism on one hand, and limit the horizon of change in cultural reinterpretation on the other. The political consequences of such theoretic pronunciation are ambiguous at best and reactionary at worst. Section III surmises that Halley's approach to Title IX commits a series of misrecognitions: (A) theoretical; (B) political; (C) sociological; (D) ideological; and (E) historical. I conclude that it is liberal feminism, not radical feminism, which rightfully ascribes the quality of "Governance Feminism" and that liberal feminism itself is a compromise formation between the principles of equality and liberty at any particular historical conjuncture. The \#MeToo movement boldly pushes the contemporary compromise formation of liberal feminism to the left, with the hopeful result of more sexual egalitarianism. Any push to the right of this contemporary 
formation, as Halley would have it, serves to preserve the status quo,

which young global activists have raised their fists in revolt against.

\section{An Unrelenting Halley}

\section{A. Oh, Catharine!}

For much of her legal academic career, Janet Halley targeted

Catharine Mackinnon, and did so rather obsessively. ${ }^{34}$ She read the latter's

"texts closely," as those of her generation trained in the humanities were

taught to do. ${ }^{35}$ She offered a pointed critique of Mackinnon and reproduced it in various guises in a range of law review articles. ${ }^{36}$ As she did this, Halley inadvertently renewed Mackinnon's célèbre. The

${ }^{34}$ See generally Janet Halley, Split Decisions: How and Why to TaKe A BREAK FROM FEMINISM (2006) [hereinafter Split Decisions]; Sexuality

Harassment supra note 24.

${ }^{35}$ Split Decisions supra note 34 at 27-105.

${ }^{36}$ Janet Halley, Sexuality Harassment in Directions in Sexual Harassment 182, 191 ("There is a third warning note [to the MacKinnon brief], and it sounds like the last gasp of a small yellow bird."), 192 ("Here is what I think the problem with the male-female model emerges for analysis. It is just so complete and so settled. Men are over there with masculinity and superordination; women are over here with femininity and subordination."); Janet Halley, Queer Theory By Men, 11 DuKE J. GENDER L. \& POL'Y 7, 11 [hereinafter Queer Theory By Men] ("It was not too long before MacKinnon significantly departed from [her earlier] claims ... [b]y the mid-1980s she claimed to know many, many things, and to know them because women's point of view had disclosed them to her without distortion."), 18 (cultural feminism and Bersani are engaged in serious combat over the value of degradation and human erasure in sex: cultural feminism says these have been overvalued because they have been allocated exclusively to women; Bersani replies that they have been vastly undervalued through their association with women. But Bersani and cultural feminists agree, it seems, that the combat is waged on the field of "value"--a field which MacKinnon pushed over and beyond the horizon of her understanding."); Janet Halley, Rape in Berlin: Reconsidering the Criminalization of Rape in the International Law of Armed Conflict, 9 MELB. J. INT'L. L. 78, 114 (2008) [hereinafter Rape in Berlin] (" ... [W] hat is women's suffering? What is this thing that should, we all agree, be visible? One, admittedly partial, way into that question is to ask, what is rape to women who have been raped? American feminists involved themselves in the Balkans situation because they thought they knew: the women were silenced and needed IHL to help them find their voice as raped women. But not all the women they sought to represent recognized themselves in the lens provided by American feminist activists."). 
sensationalized anti-pornography crusade of the eighties died, their protagonists moved on to other causes, retired the fight, or even married. ${ }^{37}$ It's been ages since media and detractors misattributed "all men are rapists" and "all sex is rape" to Mackinnon and Andrea Dworkin. ${ }^{38}$ Halley's critiques have been published long after the wave of radical feminism. In fact, feminism proper has turned into a non-event in U.S. academia. Reflected in women's studies departments, the discourse has shifted from feminism to gender and sexuality under the heavy influence of Butler's post-structuralist theories, as well as an institutional push for watered-down interdisciplinary identity politics.

Halley sees Mackinnon's shadow and influence everywhere, and each time she protests vehemently; her cries against Mackinnon's sexrepression and radical female emancipation never tire. Halley over-credits Mackinnon with every feminist regulatory gesture that touched upon sex, even when such regulatory gestures were a serious compromise on Mackinnon's line. Halley targeted Mackinnon in the figure of other feminists, seeing them as Mackinnon's surrogates, even as they split the difference with Mackinnon's ideas. ${ }^{39}$ She even went after her, via

\footnotetext{
${ }^{37}$ Bazelon, supra note 15; Eric Hoffman, Feminism, Pornography, and Law, 133 U. PA. L. REV. 497 (1985); ANDREA DWORKIN, PORNOGRAPHY: MEN POSSESSING WOMEN (1981); TAKE BACK THE NIGHT: WOMEN ON PORNOGRAPHY (Laura Lederer ed., 1980).

${ }^{38}$ Both Mackinnon and Andrea Dworkin disavowed the statement "all sex is rape," after Playboy Magazine published the misquote in their October 1986 issue. The misquote took on a life of its own throughout media and would resound for years to come. See Cindy Richards, Fighting a Lie That Just Won't Die, Chicago Tribune (May 30, 1999), https://www.chicagotribune.com/news/ct-xpm-1999-05-30-9906030177story.html (last visited Nov. 10, 2018).

${ }^{39}$ Janet Halley, Rape at Rome: Feminist Interventions in the Criminalization of Sex-Related Violence in Positive International Criminal Law, 30 MiCH. J. INT'L. L. 1 (2009) [hereinafter Rape at Rome].
} 
Governance Feminism, when American feminist legal theorists entered the international arena to criminalize rape and sexual violence at war. Indeed, Halley sang every step they make, every breath they take...feminists want to universalize feminism!' ${ }^{, 40}$ Read Rape at Rome and you find a veritable stalker at hand. Read Rape in Berlin and Halley's critique of Mackinnon reaches a stark raving mad pitch! ${ }^{41}$ All this stalking wasn't simply for the public good, there was a hint or two of something personal, an ad hominin flair. Halley was a self-confessed former "dominance" feminist before she reimagined sex as a "force for good." 42 Halley charged dominance feminism with "invaginating"43 institutions with their oppressive radical sword, the law! ${ }^{44}$ Consequently, it must inflame Halley that for years Mackinnon has chosen the graceful strategy of rebutting personal attacks with silence.

\section{B. Aping Mackinnon}

Halley's thesis on Mackinnon is simple, once you weed through

${ }^{40}$ Sung in the tune of Police's Every Breath You Take from the 1983 album, Synchronicity. Police, EVEry Breath You TAKe, on SyNChronicity (A\&M Records 1983).

${ }^{41}$ Halley incredibly proposes that criminalizing rape at war was a bad idea for the pragmatic reason that if some men knew they would be prosecuted for rape they wouldn't be available for entering into sexual bargains with their potential victims of rape such as sparing the victim rape by many in exchange for regular rape by one! See Rape in Berlin, supra note 36, at 116. Equally incredible, she proposes in this article the term: "she let the men rape her" infra note 47.

${ }^{42}$ Bazelon, supra note 15.

${ }^{43}$ Rape at Rome, supra note 39, at 4 ("In particular, we recognized the complex way in which NG formations invaginate the State with non-state elements and their porosity to NGOs aiming to advance specific social interests. GFeminism has grown up along with NG, and surely not accidentally, has co-invented its most salient features.").

${ }^{44}$ Rape at Rome, supra note 39, at 5 (They [feminists] seek to wield the sovereign's scepter and especially his sword. Criminal law is their preferred vehicle for reform and enforcement; and their idea of what to do with criminal law is not to manage populations, not to warn and deter, but to end impunity and abolish."), 65 ("[I]ndividual rape charges would drop the Damocles sword of IHL enforcement on purely individual wrongs and harms."). 
her cryptic prose, peppered with fancy French phrases and gratuitous anthropomorphisms common among the literature professional class. A digestible way of understanding Halley's critique is through the lens of reaction formation. Sigmund Freud identified reaction formation as one of the many psychosomatic responses to external threats and internal anxiety. Wikipedia offers a crisp definition:

Reaction formation is a defensive process in which emotions and impulses which are anxiety producing or perceived to be unacceptable are mastered by exaggeration of the directly opposing tendency... Where reaction-formation takes place, it is usually assumed that the original, rejected impulse does not vanish, but persists, unconscious, in its original infantile form. ${ }^{45}$

This is not to insinuate that behind Halley's unrelenting critical assaults on Mackinnon there is an undying love (though that may very well be true). Rather, I intimate that Halley's theories take their cue, piece by piece, reacting to Mackinnon's. Halley's line might best be articulated, in theory and in politics, as an "exaggeration of the directly opposing tendency."

Alternatively, one could dissect Halley's theory aptly by using the tenets of Marxism; think of Halley' conjectures as the perfect idealist gesture in which Mackinnon is stood on her head. For Mackinnon, gender is one of the social axes that create conflict in society (class being another), which women (like the proletariat) need to collectively struggle to

${ }^{45}$ Reaction Formation, WIKIPEDIA (last visited Jan. 01, 2018), https://en.wikipedia.org/wiki/Reaction_formation. As it happens, Freud's favorite example of reaction formation is the homosexual who is a homophobe. 
overturn. Gender is the regime that screws them. ${ }^{46}$ For Halley, gender, and all its manifest injuries, are fictions, "just in women's heads." 47 Injuries are an expression of bad-for-sex ideology propped up by "Governance Feminism." Injuries will simply go away if women stop inventing them! ${ }^{48}$

Halley attacks the dominance feminist thesis by performing an analytical summersault, the goal being to radically undo the (radical and partly liberal) feminist association of sex with injury, which has been the object of decades of feminist political mobilization. Halley does not seek to qualify the association or bring nuance to it, but to dismantle it altogether. The feminist proposition has always been that women suffer injury. When feminism emerged, it gave women's injury a name and a political foothold to mobilize change. Feminism named the regime it sought to change patriarchy/male domination (or "gender discrimination"

${ }^{46}$ Its materiality lies in the "sex taken." Catharine MacKinnon, Feminism, Marxism, Method, and the State: An Agenda for Theory, 7 Signs 515, 531 (1982) [hereinafter Agenda For Theory] ("According to the revision, one "becomes a woman" - acquires and identifies with the status of eth female - not so much physical maturation or inculcation into appropriate role behavior as through the experience of sexuality: a complex unity of physicality, emotionality, identity and status affirmation. Sex as gender and sex as sexuality are this defined in terms of each other, but it is sexuality that determines gender and not the other way around. This the central, but never stated of Kate Millets, Sexual Politics, 37 resolves the duality in the term "sex" itself: what women learn to "have sex" in order to "become woman" - woman as gender comes through the experience of, and is a condition for, "having sex"- woman as sexual object for man, the use of women's sexuality by men. Indeed, to the extent sexuality is social, women's sexuality in its use, just as femaleness is its alterity.").

${ }^{47}$ See generally Rape at Rome, supra note 39; Rape in Berlin, supra note 36 at 113 (Halley postulates rape as an ideology, one that is suspect and manufactured, "we might bring some scepticism to feminist representations that carry forward the 'worse than death' figuration of rape").

${ }^{48}$ Split Decisions, supra note 34, at 20-22 ("In some important senses ... feminism rules. Governance feminism. Not only that, it wants to rule. It has a will to power. And not only that, it has a will to power-and it has actual power ....") (original emphasis). 
in the liberal version). Halley's summersault follows: (1) there is no sexual injury in fact; and (2) there is only injury in and according to "feminism." When women complain about sexual injury, they lie, they manipulate, and/or they act in bad faith. Therefore, our ontological and legal posture towards women must merit radical, unflinching suspicion. In Halley's paranoid vision, women are complaint-happy. ${ }^{49}$

In lieu of patriarchy, or discrimination in the liberal version, there is "Feminist Governance." 50 Halley regards this term as an allencompassing regime of hegemonic phallic feminists have managed to "invaginate" our institutions and minds "with law, their sword." ${ }^{51}$ If radical feminism complicates the classification of consent by arguing for legal regulation to prosecute cases that do not appear to be consensual sex on their face, then Halley complicates it reversibly by reinterpreting traditional rape as consensual sex. If radical feminism hyperbole cries intercourse is rape, Halley counters with rape may very well be

\footnotetext{
${ }^{49}$ Janet Halley, Trading the Megaphone for the Gavel in Title IX Enforcement, 128 HARV. L. REV. F. 103 (2015).

${ }^{50}$ Janet Halley et al., From the International to the Local in Feminist Legal Responses to Rape, Prostitution/sex Work, and Sex Trafficking: Four Studies in Contemporary Governance Feminism, 29 HARV. J. L. \& GENDER 335, 340 (2006) ("'Governance Feminism] is, I think, an underrecognized but important fact of governance more generally in the early twenty-first century. I mean the term to refer to the incremental but by now quite noticeable installation of feminists and feminist ideas in actual legal-institutional power. It takes many forms, and some parts of feminism participate more effectively than others; some are not players at all. Feminists by no means have won everything they want--far from it--but neither are they helpless outsiders. Rather, as feminist legal activism comes of age, it accedes to a newly mature engagement with power."). While Halley has a good, elegant definition of "Governance Feminism," I find that the concept's affective life is indistinguishable from the conservative "Feminazis": the feminist who is happy to use state power "to cut your dick".

${ }^{51}$ See supra note 38.
} 
intercourse. ${ }^{52}$ Insidiously, Halley coined the phrase "she let the men rape her." ${ }^{53}$

In the radical feminist thesis, sex is what men take from women thereby subordinating them. Halley antithetically asserts when women consciously withhold sex from men, they are not inducing disappointed blue balls or adolescent anger, rather women are subordinating men. ${ }^{54}$ In other words, by sheer deprivation, sex is what women take from men, forcing an inverse of the male-authored dominate/subordinate relationship. According to Halley, rules should not be designed or implemented to protect women from "male sexual abuse" (in fact she

${ }^{52}$ See supra note 41 for the historical media construction attributing the quote to radical feminists Mackinnon and Dworkin.

${ }^{53}$ Rape in Berlin, supra note 36, at 106 ("During the first days of occupation the Woman and her first 'wolf' had persuaded the widow to let herself be raped by a man so violently threatening that he filled everyone with dread."), n.119 (Several readers have balked at my locution here: she let herself be raped? Rape is coerced, by definition, they say; coercion is inconsistent with permission; no one can let herself be raped. But see for yourself if that protocol actually helps you to understand the passage in which the widow both suffers coercion and decides ... If you don't have a concept of coerced-but-consented-to rape, you can't call this a rape. As we've seen, feminists who seek to eliminate the consent defense do so on a theory that the widow's choice was itself coerced and not in fact a choice--but the Diary strongly suggests that she, and everyone else involved in the decision that she should be raped for the common good, did decide. Whether you therefore want to criminalize it as rape-- in particular whether you want to give it the same legal treatment as entirely coerced sexual contact--is entirely another question.").

Ironically, this quote and her inane rationale does not find its way into the New York Times article.

${ }^{54}$ Queer Theory By Men, supra note 36, at 36-37 (“. . . [I]f heterosexual men experience women's sexual autonomy as a threat - not only their power to deny men something they want very much, but also their ability, in providing it, to humiliate, disorient, and abject them - then there is a second tolerated residuum of risk to take into account: men's. .. [W] advantage whenever men want them to produce the effect of bold, indifferent female sexual autonomy and are willing to make concessions to get it. On this side of the ledger, if Kennedy had filled it in, he would have said that men not only come into bargaining with women with a distinct source of bargaining disadvantage, but they also seek complex erotic goods, so that they might, over the full range of bargains that they make with women, find themselves in subordination.") 
argues for repealing many of the preexisting ones), rather, women should wake from the vicious governance regime of feminism, which implanted in them the very concept of injury. In Halley's line of gender/sex theory, injury has zero factual reality. Injury is a mere psycho-manifestation, an aging specter of radical dominance. Halley has never seen a sexual injury that impressed her - not rape, not gang rape, not even rape in genocidal conflict.

...You see the reaction formation?

\section{Inducing Ambivalence in Others}

Halley's theories could also be seen as an ideological descendant of a strand of "sex positivism." 55 She attempts to elevate sex positivism within legal academia by offering it the tangential resources of queer theory. ${ }^{56}$ In other words, Halley offers sex-positive "liberalism" the prestige of fancy theory. This parallels Mackinnon offering feminism, mired in "discrimination talk," the prestige of social theory developed by Marxist-educated leftist boys.

The sex positive position has historically been antagonistic to Mackinnon. Sex positive proponents accused her animus theories as "bad for sex" and provocatively challenged her in the anti-pornography wars. ${ }^{57}$ Those who populated this strand, and in so far as they sought to express

\footnotetext{
${ }^{55}$ See generally Lisa DugGan \& NAN D. Hunter, SEX WARs: SEXuAl DisSent and Political Culture (2006) [hereinafter Sex Wars]; CAROL VANCE, PleASURE AND DANGER: EXPLORING FEMALE SEXUALITY (1984); Janet Halley, The Move to Affirmative Consent, 42(1) SIGNS 257 (2016).

${ }^{56}$ See generally Queer Theory By Men, supra note 36; Split Decisions, supra note 34 .

${ }^{57}$ Id.; see also Bazelon, supra note 15.
} 
their "sex positivism," had a special affinity with liberal theory. They paraded concepts such as women's "agency," "consent," and "contract" to counter Mackinnon's Marxian-like critique of liberal "consent," which was rendered meaningless against the backdrop of gender hierarchy. ${ }^{58}$ This camp used liberalism as a platform to campaign for the love of sex and decriminalize sexual expression in cases where non-coercive sex was concerned. ${ }^{59}$ By all accounts, sex positivism advocates should rally behind Halley in her Title IX deconstruction to promulgate unadulterated sexual freedom on campuses nationwide. Sadly, they are absent.

By aping Mackinnon through "exaggeration of the directly opposing tendency," Halley induces ambivalence among the sex positivists. She does so because she bulldozes in the wake of her theorizing even liberal ideas about violence as the limit of consent. Halley wastes a ton of ink whitewashing violence against women by framing it as a prude female fairy tale or questioning its quantifiable harm. Halley asserts that

\footnotetext{
${ }^{58}$ See generally Sex Wars, supra note 55; Queer Theory By Men, supra note 36, at 13 ("[] MacKinnonite feminists and cultural feminists began in the early 1980s to converge on some fairly specific targets of activism--rape and other forms of direct violence, pornography, intergenerational sex, sex between social unequals (for example, boss/secretary, teacher/student), sex in public-- as leverage points for the de-subordination of women.8 They formed important alliances with social and religious conservatives morally opposed to these practices, and together these allies made significant progress in articulating and enforcing legal sanctions against a wide array of sexual relations. This simultaneous turn "to the state" and "against sex" broke alliances between MacKinnonite and cultural feminists on the one hand and radical, sexualliberationist feminists on the other. The result was the "sex wars." In them, the radical, sexual liberationist feminists precipitated abruptly and with great energy out of male/female-model and cultural feminism, and, looking back to the radical feminist sources from which MacKinnon's early work emerged, formed a distinct "sex-positive" feminism specifically in struggle with LateMacKinnonite and cultural feminism.").

${ }^{59}$ Queer Theory by Men supra note 36 at 33 ("[Mackinnon] rigorously maintains her stance of not knowing the difference between rape and a good fuck.").
} 
violence is open to semiotic interpretation, ${ }^{60}$ and that, surely, there are things worse than violence against women. By defending and qualifying violence and coercive sex, Halley negates the liberalism of this camp inducing it to silence. ${ }^{61}$

The reaction of ambivalence demonstrates that Halley is actually aping Mackinnon in the opposite direction on the spectrum. Mackinnon herself had historically induced ambivalence in liberal feminists who struggled with the particulars of Mackinnon's legal reform career. Liberals grappled with what kind and how much reform was necessary in sexual harassment and rape law. Mackinnon's posture, that much of consent is "coercive," left many liberals vacillating with doubt. Halley inversely does the same.

The Mackinnon/Halley duel is as an encounter between two positions each articulated in maximalist fashion. For Mackinnon, much of consent is deemed coercive, whereas for Halley, much of coercion is deemed to be consented to. The absolutist quality of these two adversarial positions is a function of the dominant liberal-orientated positions within legal feminism. Mackinnon's radical Marx-like arguments and Halley's

${ }^{60} I d$. at 44-48. Halley engages in a discussion defining the "completely reversed image" of the subordination/domination paradigm, asking: "Can feminism acknowledge that women emerge from the court's decision with new bargaining power in marriage and a new role as enforcers of marital propriety? And can feminism see how costly this "bargaining endowment" might be to women, who can tap into it only if they find the sex in question painful and humiliating? Can feminism read the case as male subordination and female domination--and still as bad for women?"

${ }^{61}$ Even more paradoxically, Halley's devalidation of women's non-consensual injury claims make her real adversary in fact, liberal feminists, but yet "crosseyed-ly" she directs most of her ire at Mackinnon in a classic case of political misrecognition. (cite/support?) No need for cite for this because it is a logical argument. 
unfettered pre-realist libertarianism equally affront this dominant feminism. ${ }^{62}$ By aping Mackinnon, Halley has aped the tragedy of isolation within the academic feminism.

\section{Theories on Gender/Sex by the Non-Liberal Academic}

\section{Left}

In this section, I offer a condensed account of the theories on gender/sex that are a hallmark of a generation of non-liberal leftist academics. The point of this exercise is to highlight the substantive shifts in theory over the past several decades which identify, influence and, too often, infect society's gender/sex paradigms. Mackinnon's objectivist social theory plotted the gender revolution by taking a cue from the sociality of gender relations. When Butler's discourse theory substituted discourse for society, the substitution became the consequence of its origin; it locked people inside the discourse itself, with individual performance as the only means of escape. ${ }^{63}$ Butler's formulations of individual performance subvert this manufactured discourse and dissimilate "being” from "doing." Alternatively, Kennedy’s subjectivist theories substitute culture for society and interpret away the bad stuff. The most recent shift in Halley's line of radical skepticism treats society as the sum of individual interactions none of which reflect a larger social

63 Judith Butler, Performative Acts in Gender Constitution: An Essay on Phenomenology and Feminist Theory, 40 THEATRE JOURNAL 519, 527 (1988) [hereinafter Performance Acts] ("Gender reality is performative which means, quite simply, that it is real only to the extent that it is performed. It seems fair to say that certain kinds of acts are usually interpreted as expressive of a gender core or identity, and that these acts either conform to an expected gender identity or contest that expectation in some way.") 
structure. Her aestheticism module substitutes literary commentary for social commentary, and her tainted idealism translates social transformations into mere illusions. These shifts are not just theoretical but deeply political. They move the gender/sex pendulum from the consequence of social hierarchy to a cultural ruse hindering sexual liberation believed to be an invention of anti-sex "feminazis." The upshot of these shifts is the re-direction of animus away from the problem of male sexual entitlement to the root cause of "fucking" tied to gender-bending, wherein feminism is not the spokesperson for subordinated women, but a discourse formation suspect for sex biologism and "anti-sex(i)ness" to which women's animus should be directed.

\section{A. Catharine Mackinnon on Gender/Sex (Marxist-like)}

According to Mackinnon gender is the result of social conflict. It is a byproduct of hegemonic social relations, in which male supremacy coercively dictates normative behavior, wherein "no women escapes the meaning of being a woman." ${ }^{64,65}$ The conflict revolves around sex/sexuality, wherein men push for, insist on, and assume the right to appropriate women's sexuality. As “male is the explicit reference to human," they naturally get the better deal. ${ }^{66}$ Simply, they are on top and women are at the bottom. ${ }^{67}$ This regime is called male domination. "Male domination" here is not a reference to specific individuals but to the

\footnotetext{
${ }^{64}$ Catharine MacKinnon, Feminism, Marxism, Method, and the State: Toward Feminist Jurisprudence, 8 SIGNS 635 (1983) [hereinafter Toward Feminist Jurisprudence]

${ }^{65} \mathrm{Id}$. at 640.

${ }^{66} \mathrm{Id}$. at 643.

${ }^{67} \mathrm{Id}$. at $635-36$.
} 
system as a whole. ${ }^{68}$ It develops its stability and strength through the eroticization of this domination by both men and women. Through the eroticization of domination both men and women, acquire an investment in the regime, an investment in the status quo (though far more by men than by women) ${ }^{69}$

The conflict around sexuality might be termed the material aspect of the conflict, represented by social practices in which women "give" men "sex" as their femininity—-their woman-ness — requires. Men, in turn, act as the entitled recipients of this manipulated "offer," for it is owed as their man-ness is construed. Given that women do not dictate the terms of their own "femininity," extant femininity is completely constructed by the regime of male domination. ${ }^{70}$ Eroticization of this domination might be termed its ideological aspect, where the unequal exchange is experienced as "sexy." The "erotic" is not only lived in the mind, but also materially in the body; it is somatized. As a result, within the regime of male domination, and uniquely so, the material lives ideologically (in consciousness) as much as the ideological lives materially (in the body). Through consciousness-raising, women, as a social group, begin to comprehend, question, and viscerally grip the essence of the regime by drawing a connection between their varied experiences, which are otherwise experienced as individual, isolated and unique. Women are thus empowered as they identify with the collective aspect of their experience. ${ }^{71}$

${ }^{68} \mathrm{Id}$. at 638 .

${ }^{69}$ Agenda For Theory supra note 46 at 533; Toward A Feminist Jurisprudence, supra note 64 , at 650 .

${ }^{70}$ Toward A Feminist Jurisprudence, supra note 64, at 638-39.

${ }^{71}$ Agenda For Theory, supra note 46, at 519-20, 535. 
Feminism is the politics that names the regime, identifies its institutional structures, and mobilizes women for the purposes of changing such structures. Feminism deploys consciousness-raising as its method to identify and describe the nature (the " $i s$ ") of social institutions. Feminism, in this sense, has a dual condensed role - it names the regime (descriptive) in order to change it (transformative).

Mackinnon's "male domination" regime is inherently conflictual. As historically established and institutionally enforced, males' objective interests lie in the strength and preservation of the regime which keeps them on top. ${ }^{72}$ Their interests, naturally and directly, clash with the objective interests of women, which embody that of the undoing or dismantlement of the regime. ${ }^{73}$ In other words, within domination lies the seeds of insubordination. The system, or regime, is understood to be objectively dynamic.

This dynamism, understood as a bubbling clash of interests underneath a calm surface of stability, acquires a lurch forward, a qualitatively different leap or momentum, once the objective interests of women are experienced in their consciousness as a collective, (i.e., once they are experienced simultaneously and subjectively). Feminism, hence, is the politics expressive of this realization. Feminism, in this theory, represents women in a dual sense: it represents women's situation, i.e., it

\footnotetext{
${ }^{72}$ Karl Marx, THE COMMUNIST MANIFESTO AND OTHER REVOLUTIONARY WRITINGS 126 (Bob Blaisdell 2003) ("In early history epochs, we find almost everywhere a complete organization of society into various degrees, a manifold graduation of social rank."

${ }^{73} \mathrm{Id}$. at 134. (The proletariat [woman], the lowest stratum of existing society cannot stir, cannot raise itself up without the whole of the higher strata forming official society being sprung into the air.")
} 
describes it through language, but it also represents women's objective interests, i.e. it speaks for them. These sets of arguments rely on an idea of the truth of gender, the "is" of gender, which the role of feminist theory represents. Because gender is understood as an effect of social conflict, produced as people enter into social relations with each other, this theory understands change as being fundamentally and necessarily social. Nothing short of a transformation within social relations, and the institutions that embody them, accounts for a qualitative change within gender relations. It must be emphasized that law and legal relations are one of many such social institutions that can influence, if not force ideological and material change.

\section{B. Judith Butler on Gender/Sex (Foucault-like)}

Butler revisioned gender as the effect of discourse. ${ }^{74}$ Butler offered discourse as an institutional, political, and linguistic representational system that produces gender as a genealogical effect. ${ }^{75}$ Gender production manifests through an ideational ruse. Here, discourse creates and operates through a kind of necessitarian logic that strings along sex with gender and sexuality (desire), thus naturalizing and necessitating

\footnotetext{
${ }^{74}$ To expose the foundational categories of sex, gender and desire...requires a form of critical inquiry that Foucault, reformulating Nietzsche designates as "genealogy." A genealogical critique refuses to search for the origins of gender, the inner truth of female desire, a genuine or authentic sexual identity that repression has kept from view; rather genealogy investigates the political stakes as an origin and cause the identity categories that are in fact, the effects of institutions, practices, discourse, with multiple diffuse points of origin." Judith Butler, GENDER TROUBLE: FEMINISM AND THE SUBVERSION OF IDENTITY viii (Linda J. Nicholson 1990) [hereinafter GENDER TROUBLE].

${ }^{75}$ Using a line of necessitarianism, in regard to Butler's (and Foucault's) discourse ideology allows for a rather simple parallel for essential, determinate and fixed categories of social sanction.
} 
coherence and continuity between these three elements. ${ }^{76}$ Once a body is hailed "female," then notions of "woman" and "heterosexual" identity prevail as the (dis)course, concealing the indeterminacy of the connection. ${ }^{77}$ Butler names this regime, Compulsory Heterosexuality. It also appears in broader literary texts as Phallogocentricism. ${ }^{78}$ In so far as feminism asserts representation of women, its results are comparable and compatible with the regime of Butler's Compulsory Heterosexuality. Feminist theory, as aligned with predisposed binary dominance, or performance, should therefore be treated with utmost suspicion. ${ }^{79}$ Feminism as theoretical discourse is suspect for three reasons: (1) it assumes a "subject" of feminism (woman), and, consequently, naturalizes that "subject;" (2) by assuming the subject of "woman," it naturalizes the paradigm of gender/sex; and (3) by assuming a universal category of "woman," which cuts across cultures and other identity axes, it assumes a pre-discursive "woman" who precedes and tramples culture, race, class, and other. ${ }^{80}$ In short, what feminism is denying is that-as representational discourse - it is producing the very "woman" it claims to

\footnotetext{
${ }^{76}$ GeNDER TROUBLE, supra note 74 at 6-7.

${ }^{77} \mathrm{Id}$. at 6-7.

${ }^{78}$ See generally Jacques Derrida, De La Grammatologie (1967) (extending logocentrism to phallogocentrism, the privilege of the masculine within the construction of a "system of metaphysical oppositions").

${ }^{79}$ Gender TRouble, supra note 74, at 13.

${ }^{80}$ Performative Acts, supra note 63, at 523. ("The discourse of feminism has often relied on the category of women as universal presupposition of cultural experience, which in its universal status provides false ontological promise of eventual political solidarity. In a culture in which the false universal of 'man' has been for the most part predisposed with the coexistence of humanness itself...").
} 
represent thereby acting as its own system of power (that regulates, prohibits, disciplines, excludes, etc.). ${ }^{81}$

Butler's Compulsory Heterosexuality is subverted when the relations of coherence and continuity connecting sex, gender, and desire are exposed as contrived. Breaking from the historical performance of heterosexuality emancipates the relationship of sex, gender, and desire, allowing the elements to be indeterminate. It should be restated, Butler's grounding tenet is there is no truth of gender, but merely a performance of it. Subversion occurs when individuals perform gender differently and when they repeat their performances differently. Drag performance is an example of such subversion; it shows the theatre and performativity of femininity ${ }^{82}$ Butler admonishes feminism to drop the idea of representing the universal "woman," ${ }^{83}$ subvert its will to power, and, alternatively, adopt a politics premised on temporary alliances expressive of temporary identities which dissolve with the identities themselves. ${ }^{84}$ Accepting Butler's Foucault-like set of gender arguments is accepting a radically objectivist theory of the world, a militant 'wall to wall' discourse, wherein the very "subject" is no more than an ideological ruse of the "object." 85 Everything is a discursive effect: sex, gender, desire, the body, the presupposition, even the taboo. Whether voluntarily, or not, we are inside the ideology tout court, where the "is" always was. In this claustrophobic

${ }^{81}$ GENDER TROUBLE, supra note 74, at 141 .

${ }^{82} \mathrm{Id}$. at 146 .

${ }^{83} \mathrm{Id}$. at 15 ("Is "unity" necessary for effective political action?"), 142-49.

${ }^{84} \mathrm{Id}$. at 16 (" . . . it will be an open assemblage that permits of multiple convergences and divergences without obedience to a normative telos of definitional closure.").

${ }^{85}$ Butler's Gender Trouble marries Foucault to Freud to Hegel. A kind of theoretical pastiche that is hard to follow and even harder to explain to students. 
universe of "wall to wall" discourse, the only way "out" is through disruption of the very resources of discourse itself. Within these precepts, there is no a real "out," rather there is only an "in," which manifests in a unique way.

In further deconstruction, "gender" subversion occurs when gender is performed differently, but since the "subject" is dead, it is unclear who is actually performing what, and how they are performing differently. Who is making the calculations to disrupt and why? Moreover, how is performing differently a disruption? Is the norm disrupted by a single different performance, or does disruption require two? What about ten? Or it is hundred? Is there a cumulative magical number of "different performances" after which the discourse on gender starts to shift? In this theory, the dynamic of "disruption" divides the actors into a dyad of performance and audience. How, in this dyad of performance/audience exchange, will social institutions change? It appears that having "killed" the subject, this theory resorts to the "performative," to perform the functions of this dead subject. Indeed, the performative sounds very much like the individuals of liberalism who sway their enraptured audiences to change their minds on gender! This theory teeters on suggesting that the "individual" performer changes the "social."

If there is no way out of "discourse," if subverting one discourse simply means entering into another, then in this theory "emancipation" does not exist. Subversion is simply an entry point into an alternative system of power. Butler's "discourse" which emancipates us, is the same 
one that dominates us! We find ourselves as the Beautiful Soul living on the margins in perpetuity, while simultaneously and paradoxically melting norms through a single powerful performance. ${ }^{86}$

\section{Duncan Kennedy's Theory on Gender/Sex: "Sexy Dressing:" Splitting the Difference between Liberal Feminism and Radical Feminism}

Duncan Kennedy offers a theory of gender/sex from the position of a "white middle class man allied with pro-sex feminism." ${ }^{87}$ Honorably, Kennedy denounces the regime he names as "male sexual abuse" and asserts he would like to see less of its ills. Kennedy's definition of “male sexual abuse" is more expansive than the liberal feminist, "sexual violence," but less expansive than Mackinnon's "male domination." Rather than using social theory or post-structuralist theory, as Mackinnon and Butler did respectively, Kennedy deploys legal language, rules, and tolerated residuum, coupled with the economic language of wins and losses, to describe his gender/sex dyad. ${ }^{88}$ According to Kennedy, male sexual abuse exists in the "tolerated residuum." ${ }^{89}$ Simply, tolerated residue of abuse is a result of the failure of extant rules to narrowly address abuse and a failure of their institutional enforcement. As a radical pro-sex male ally, Kennedy asserts that passing more rules and enforcing extant rules will decrease male sexual abuse. The thru line of his argument is that the

\footnotetext{
${ }^{86}$ Martha Nussbaum, The Professor of Parody, THE NEw REPUBLIC (1999), http://faculty.georgetown.edu/irvinem/theory/Nussbaum-Butler-Critique-NR-299.pdf.

${ }^{87}$ Duncan Kennedy, Sexual Abuse, Sexy Dressing, and the Eroticization of Domination, 26 NEW ENG. L. R. 1309, 1310 (1991-1992).

${ }^{88} \mathrm{Id}$. at 1323-27 (delineating the "cost" to women of insisting on precautions, the "burden" of excess enforcement, and the "benefits" to men).

${ }^{89}$ Id. at 1314 .
} 
less male sexual abuse there is in the world, the more women are free to offer sex to men, which is titillating and well-deserved..$^{90}$ e However, Kennedy recognizes that his objective interests as a man would naturally lean in the opposite direction, the direction of increasing tolerance for the residuum of abuse. ${ }^{91}$ Stricter rules and stricter enforcement of extant rules would, ostensibly, minimize abuse exposing him, as a man, to a larger number of "unpleasant" experiences such as being charged unfairly with peeping in the Gap store fitting room (women be damned). ${ }^{92}$

Kennedy addresses the "sex" part of the gender/sex dyad as a postmodern theory on culture, wherein popular culture is treated as an interpretational text that he then marries with phenomenological accounts of sexual acts. He expounds this cultural ideology through his indulgent discourse of "sexy dressing." According to the male ally, "sexy dressing" is a form of clothing worn to intentionally produce "sexual interest, arousal, excitement... ${ }^{, 93} \mathrm{He}$ explains unapologetically, from a rather basic foundation, "[b]ecause sexy dressing violates the norm for the setting, the straight male reaction is complicated."94 Kennedy proposes that this complicated discourse of eroticized fashion does not merely reproduce "male sexual abuse" a la radical feminism, but offers women agency in a

${ }^{90} I d$. at 1390 ("I think that men and women might fantasize, play, experiment, and innovate more, and perhaps more happily, if there was less ... danger."), 1393 (explaining that "[a]buse screws women up sexually, and that's bad for men," that it "discourages" women from taking sexual — and pleasurablerisks).

${ }^{91} I d$. at 1326.

${ }^{92} \mathrm{Id}$. at 1325 .

${ }^{93} \mathrm{Id}$. at 1345 .

${ }^{94} \mathrm{Id}$. at 1346. 
"perverse reversal." 95 The sexy dresser (always women) may be turning the power table on the sexed (always men). Kennedy dangerously suggests that women, in their voyeur luring fishnets and mini skirt, may be using "the master's tools [to dismantle] the master's house."96

There is much to note about Duncan Kennedy's left postmodernist theory of gender/sex from the position of a feminist ally. Understood as left-of-liberalism, Kennedy's gender/sex scheme can be categorized as left-liberal reformist. With his construct of more rules, less abuse, plus a "resistance" virtue gleaned from the status quo, it is hard to understand in what sense Kennedy is a "radical" (as he self-describes). His relationship between ideological orientation and objective interest is wholly conflicted. How are we to reconcile his rational objective interests as a man, who pushes for more abuse, with his ideological orientation as a pro-sex feminist ally campaigning to minimize abuse? Kennedy appears to warn us that beneath the ally, lurks a "man." Kennedy is signaling, perhaps, that his "ideological appetite for change" is limited by the objective interests of the man.

Kennedy asserts that there is no out of "the culture" of male sexual abuse, that humanity is born into it and all we can do-as fuckers within it — is tinker with its predetermined elements. We might call this tinkering "resistance." However, Kennedy fails to clarify how survival within this predisposed culture is distinguished from the resistance thereof? It is

${ }^{95} I$ d. at 1342-54. Kennedy notes that "sexy dressing" can be a deviance of the norm for non-convention female beauty found in "old women and very large and very thin women," wherein dressing as a provocateur labels them as "rebels, or eccentrics or "desperate."

${ }^{96} \mathrm{Id}$. at 1339 . 
unclear how "resistance" actualizes within the regime of abuse. Is it doing anything more than validating aroused participants (no shame, no fear, and a hard on)?97 Kennedy offers descriptions of "resistance" on the "phenomenological level," exploring resistance via the feelings of participants. In Kennedy's regime of male sexual abuse, resistance appears to be a hallmark of permission, permission to be erect with thoughts of egregious domination. What exactly is the sum total of shameless hardons accompanied by rape fantasies which will leave a dent on the regime of male sexual abuse?

Kennedy contrasts abuse with sex; the former is described "objectively" through the medium of rules and "wins and losses," and the latter is described "subjectively" through the medium of culture, as interpretive text, and through phenomenological descriptions via the psychological. Kennedy isolates and relativizes "sex" through interpretive text. But is "abuse" not also relativized? Halley claims that abuse is subjective, in your head! Moreover, if our relationship to the structure of male sexual abuse is mediated by signs that split us into "interpretive communities" ("sex/danger/post-modern resisters" coexisting with "sex vanilla interpreters" coexisting with "anti-sex feminist interpreters" coexisting with "religious 'total woman' interpreters") do we not end up with a flat network of "differences," a multicultural pluralism of difference, rather than "resistance" proper?

Kennedy's theory, in virtue, naturalizes gender differences by

${ }^{97} I d$. at 1365. "Coercion, engulfment, compulsion and sexual abuse are real...Pleasure and resistance relate to them (it seems) symbiotically, even parasitically, rather than a permanent obliteration or replacement of the regime." 
creating the always male binary voyeur and the always female sexy dresser. He replaces the radical feminist scheme of "men on top/ women at the bottom" with "men looking up your skirt/ women wearing skirt." Kennedy produced a hundred pages or so to that effect without the slightest conjecture to subvert the male/female roles $!^{98}$ By creating this tight sexual ontology of gender, even if power equally resides in the sexing-up "object" and the voyeuristic "subject," Kennedy draws the limits of his own "resistance" project. His all too predictable binary is the abiding framework for the proposed political disruption of "male sexual abuse." In sum, what Kennedy's theorizing of gender/sex offers is not social transformation but a movement along a spectrum to the left in the direction of minimizing male sexual abuse that is nevertheless threatened from within the same theoretical schema he offers to slide back to "the objective interests of men," a relativizing gesture of the resistance scenario that turns it from "resistance" to cooptation, and a set ontology of sexual interaction in which women seduce and men are seduced. What is uniquely missing is an account of Kennedy's pro sex partner, when male sexual abuse penetrates her consciousness as a threatening system, herself sliding back to her own "objective" interests as a woman, turning her sexiness into animus and gazing back at him firmly asserting: enough is enough. In that

\footnotetext{
${ }^{98}$ The strangeness of this comes from the fact that Kennedy was known among his graduate students as a seducer exhibitionist who sat beside his desk stretching his feet on it, lifting his crotch up at an angle that very much offered his students, the up of "his skirt", and he did it habitually as if insisting that "sex" was indeed a text in this office to be read and thought about by his students though never discussed (except through the medium of what he wrote). It appears that thinking of himself as an object of a gaze rather than its subject was so terrifying to Kennedy that not the lightest attempt at exploring it is made in his paper on Sexy Dressing.
} 
"enough" there lies the politics of transformation.

\section{Janet Halley's Queer Theory on Gender/Sex: Radical Post-}

\section{Modernism}

While Mackinnon aspired to give feminism the dignity of theory, Halley aspired to give sex positivism the dignity of theory. Halley's queer theory stands Mackinnon's radical feminism on its head. ${ }^{99}$ If for Mackinnon sex is gender (gender needs sex to eroticize and consequently naturalize gender hierarchy), then for Halley gender is sex (sex needs gender hierarchy to happen, to heat things up, we need gender to fuck). ${ }^{100}$ For Mackinnon, gender is weighted by the social and glued by the ruse of the erotic, whereas for Halley, gender is unbearably light, voluntarily adopted, and dropped, its hierarchies are the very stuff of sex. For Mackinnon, male dominance is the culprit behind gender hierarchy, and requires feminism to overturn it. ${ }^{101}$ For Halley, "Governance Feminism" is the culprit which implants sexual injury in women's heads and threatens to stabilize gender and overturn the erotic potential of gender play. ${ }^{102}$ In this sense, Halley differs significantly from Butler. Butler's "performer" struggles on the margins to disrupt the discourse of gender and is only successful by "repeating" gender differently as the constraint of the

\footnotetext{
${ }^{99}$ Split Decisions, supra note 34, at 41-58; see generally JANET HALLEY, Sexuality Harassment, in DiRECTIONS IN SEXUAL HARASSMENT LAW 182 (Catharine MacKinnon \& Riva Siegel eds., 2004).

100 Split Decisions, supra note 34, 165-67.

${ }^{101}$ See generally Agenda For Theory, supra note 46.

102 Rape at Rome supra note 39 at 3 ("We developed this term [Governance Feminism] in part because it captures the strong resemblance of the new, muscular non-governmental organization formations adopeted by feminists for the prescription of political engagement with law produced by the New Governance (NG) school"); See generally Split Decisions supra note 34 (discussing the implantation of sexual injury).
} 
discourse is too overwhelming. In contrast for Halley, one wears gender and takes it off like one wears a condom and takes it off. In fact, in Halley's imaginaire, gender performs the exact same role as the condom. Gender's relationship to sex is one of functionalism. Simply put, according to Halley, we are gendered to fuck; we are gendered to heighten our sexual pleasure. ${ }^{103}$ While Halley stands Mackinnon on her head, she destabilizes Kennedy's careful “difference splitting."104 Halley counters Kennedy's "male sexual abuse" with "sexual subordination of men by women" as an alternative frame for dyadic interaction centering on sexual injury. This alternative frame effectively pushes Kennedy's left-of-liberalism theory backwards along the spectrum towards classical liberalism. If each sexual interaction is unique, and if "male sexual abuse" can be countered by "women blue-balling men," (my words) and if one acknowledges that power moves in mysterious ways, unknowable a priori (the Foucaultian idea), then one has to weigh everything against everything else. ${ }^{105}$ There is

103 This carnal relationship between gender and sex is a slight modification of the conservative religious dynamic. Halley replaces 'we are gendered to reproduce,' with 'we are gendered to fuck.' Halley is very moralistic, indeed almost fundamentalist, about her beliefs. See "Appendix" end of "Queer Theory by Men", supra note 36, in which "sex" is included in almost every paragraph of what "queer" means and where gender fashions and refashions itself in the service of sex. Halley's main argument in all Split Decisions is that feminism should be broken from so people can fuck. "Fucking" is the primary Good that Halley sets out to defend, preserve, and advocate for in her writings and while she sets out "decisionally" to look at a particular situation, not biased to one "good" over the "other", her inclination is to defend "fucking" wherever she finds and to treat it as a superordinate as value.

${ }^{104}$ Split Decisions supra note 34 at 167-86.

${ }^{105}$ Queer Theory By Men, supra note 36, at 32-33 ("Kennedy insit[s] that some, many, men have an interest in reducing the tolerated residuum - not because they are good converts to cultural feminist normativity who would sleep better at night if they knew all human beings were safer- but because they are erotically self-interested heterosexual men who could be more restless at night if women knew it was safer to be sexy to them...Eroticization of domination has "taken" in the sense that human heterosexual life seems unimaginable without it, definitely in the sense that eroticization of domination involves all men, and all women in a highly dangerous and oppressive system...the "seamless quality" of 
no privileged actor, nor privilege acted upon as social theory presumes.

We are back in effect to classical liberalism's neutrality approach.

Halley's queer libertarian theory is rooted in the complete rejection of social theory as an indulgence in the "copula" that she dismisses as a form of "moralism." 106 She replaces the "copula" with the principle of radical indeterminate-ness. ${ }^{107}$ The nature of indeterminateness leaves Halley impatient with the left's classic causes such as homophobia, misogyny, and racism as they assume too much; they assume a society. ${ }^{108}$ Halley believes each interaction is unique and contains a unique traffic of power, the terms of which cannot be determined a priori through social theory's resources. In lieu of social theory, Halley resorts to literary and aesthetic language to describe the sex of her "Queer

that system as it is described by the structural feminisms cannot account for the "fissures of existence within liberal patriarchy"').

${ }^{106} I d$. at 23 ("One of the most breathtaking tropes in MacKinnon's structuralist rhetoric, as well as in those dark cultural feminisms that take patriarchy as a transhistorical truth, is the simple word "and." Rape and pornography and sexual harassment and domestic abuse and prostitution and trafficking in women and marriage and makeup and the Boy Scouts--they are all mere instances of the structure of male dominance and are basically all alike. Following Judith Butler, we could designate this basic trope the copula ... It is the rhetorical form of many of MacKinnon's most breathtaking statements: "Socially, femaleness means femininity, which means attractiveness to men, which means sexual attractiveness, which means sexual availability on male terms. What defines woman as such is what turns men on." The tendency is, if anything, more pronounced in her later work.").

${ }^{107}$ Id. at 30 ("Recall what that structuralism means in MacKinnon's thought: the eroticization of domination precipitates women as women and men as men; it produces women as subordinated to men, by definition. In MacKinnon's thought, this is not only a social, but also a metaphysical and ontological achievement, so that no human consciousness is free of it. Sexuality as women's subordination and men's superordination pervades human reality, such that rape is merely the paradigmatic form of heterosexual interaction; and it pervades human consciousness, such that no one is in a position to say for sure that a given act of "voluntary" or "ordinary" heterosexual intercourse (or watercooler flirtation) is not precisely homologous to what we call rape. The copula, the decision to attribute to the woman who files a complaint the "truth" of all women.").

${ }^{108}$ Split Decisions, supra note 34, at 3-10. 
Theory." It is "abject" and full of "shame." It loves "metaphor and catachresis." Interestingly, her queer sex is not socially lived. It is a fictional narrative, ruminated and commentated upon by humanities departments of U.S. academia. ${ }^{109}$ Halley abandons the classical liberal ethos of "neutrality and objectivity" for a "consultation with her friends on the merits of each situation." True to the vein of post-modern writings, she offers an existentialist theory of decision, decisionism ${ }^{110}$. Without the foundation of the "social," Halley treats theory as constitutive. She pedals theories with "unbearable lightness," shifting them, switching them, and dropping them, each time seemingly reinventing the world anew. In Halley's vision, the world does not constrain theory, theory constrains the world.

\section{The Misrecognitions of Halley's "Queer" Sex Libertarian}

Project

\section{A. The Problem of Theoretic Misrecognition}

Halley's theoretical framework oscillates between advocacy of a neutral structure of wins and losses offered as a response to feminist regulation (while pulverizing Robert Hale in the process) and as a partisan agenda for dismantling feminist regulation on sex. ${ }^{111}$

\footnotetext{
${ }^{109} \mathrm{Id}$. at 151-67.

110 "We might have to decide without knowing that our understanding of the situation is right, without knowing how our decision will play out...." Queer Theory, supra note 36, p. 21

${ }^{111}$ Halley invokes Hale quite often in her writings. Hale is famous for deconstructing the ideology of the market by showing that "regulation" is everywhere in the "free market." To invoke his analysis in pushing for the ideology of "free sex" in which "regulation of sexual injury is pitted as the enemy of free sex" is indeed ironic. The only way Hale can perform the theoretic function Halley asks of his work is by turning him from a de-
} 


\section{B. The Problem of Political Misrecognition}

Halley targets radical feminism in her critique, but in fact her critique jeopardizes the theories, struggles, and victories of most liberal feminism. In response to MacKinnon, Halley bulldozes consent on her way to the "right" of the political spectrum, disregarding "consent" as a liberal sacred cow.

\section{The Problem of Sociological Misrecognition}

Halley adopts a radical sexual ideology_fucking unto deathborn from an intimate clique of gay men defending the promiscuous sexual practices of the public bath in the throes of the AIDS epidemic, an unpalatably poor fit for women's sexual biographies. Halley's tired question: "if gay men can fuck unto death, what's so bad about rape?"

\section{The Problem of Ideological Misrecognition}

Halley attempts to ally her sexual ideology with the "left," but the discourse it promotes is premised on voluntarism, individualism, nominalism and culturalism, all of which contravene leftist politics and merge seamlessly with the neo-liberal creed that we live.

\section{E. The Problem of Historical Misrecognition}

Halley promotes a form of sexual libertarianism that is indistinguishable in content from the dominant sexual ideology of the times. Halley fails to acknowledge our radically sex-positive times emboldened by a pop culture saturated with sexual hedonism, 
internet pornography, and dating apps. She echoes an aging sex preacher oblivious to her young loose and liberated congregation.

\section{CONCLUSION}

Buried within Halley's localism, nominalism, voluntarism, aesthetism, decisionism, and functionalism lies a radical sexual libertarian maximalist proposition: every form of sexual regulation aimed at gender equality threatens to undermine sexual freedom. Halley's crusade against Governance Feminism, cloaked in sex-positivism, lands her to the far right of consent. This is an unadulterated right wing proposition mirrored by conservatives who oppose regulation of destructive neo-liberal market economies.

The rise of campus rape activism, and the \#MeToo movement at its heels, reveal that there is indeed a governing feminism, but not in the fashion Halley posits. Governance Feminism is far from being the radical feminism that occupies much of Halley's obsession. Rather, it is a ruling liberal feminism with an organic relationship to ruling liberalism empowered by the latter's network of partisan organizations, activist networks, institutional power, and mainstream mass mediated discourses. Like all forms of ruling liberalism, ruling liberal feminism is a compromise formation that splits the difference between equality (liberal feminist regulation) and freedom (the sex positivism of liberal feminism which limits regulation). The rise of feminist activism is the rise of young women revolting against this institutional compromise; it is an activation to push the pendulum to the left towards equality. Young activists exhausted by the current terms of [un] equality, "screwing them," demand 
reform and demand change. Halley's fear of sexual repression blinds her to the substantive foundation of the nouveau feminist campaign, which is one of sexual freedom on women's terms. When Halley relies on her formalist articulation of more is less, she defends the status quo, the static contemporary context that triggered activists' cries of protest.

Like many of the historical social movements that preceded, controlled revolution often results in an improved, yet imperfect, compromise. Feminism is no different. When the wave ebbs, a new compromise formation will solidify, improving women's lives one regulation at a time. And in righteous hope, these regulations might actually unite and reconcile equality with freedom. 